\title{
LOCA Fragmentation Test with High Burnup HBR Fuel Rod
}

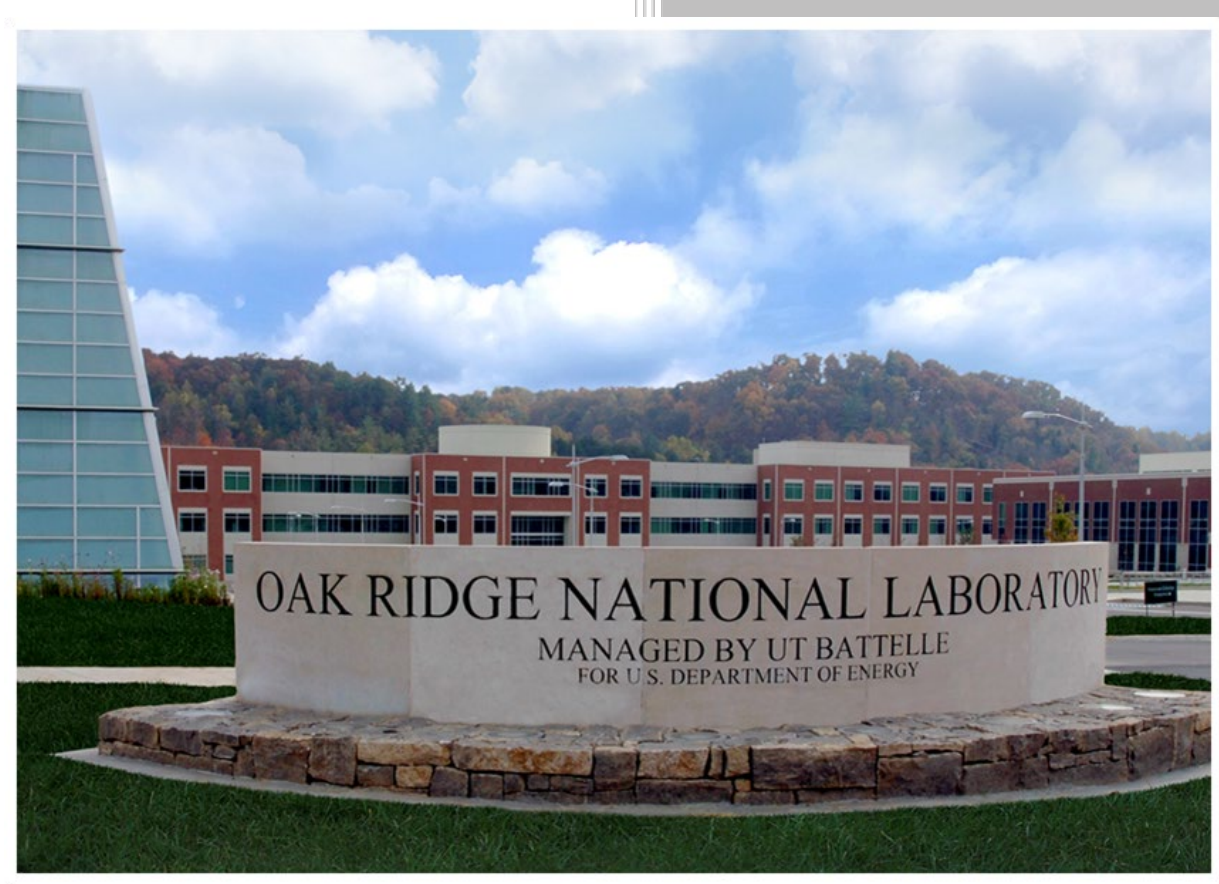

\section{Approved for public release.} Distribution is unlimited.

Yong Yan

Zach Burns

Tyler Smith Kory D. Linton Ken Yueh (EPRI)

Kurt A. Terrani

July 2019 


\section{DOCUMENT AVAILABILITY}

Reports produced after January 1, 1996, are generally available free via US Department of Energy (DOE) SciTech Connect.

Website www.osti.gov

Reports produced before January 1, 1996, may be purchased by members of the public from the following source:

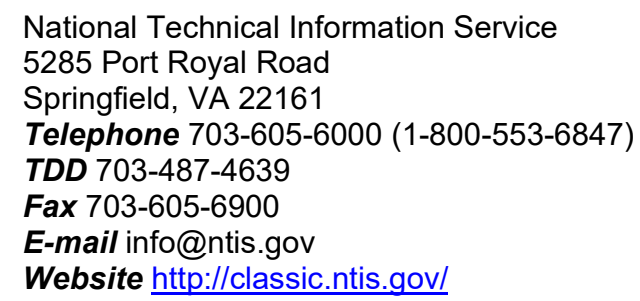

Reports are available to DOE employees, DOE contractors, Energy Technology Data Exchange representatives, and International Nuclear Information System representatives from the following source:

Office of Scientific and Technical Information

PO Box 62

Oak Ridge, TN 37831

Telephone 865-576-8401

Fax 865-576-5728

E-mail reports@osti.gov

Website http://www.osti.gov/contact.html

This report was prepared as an account of work sponsored by an agency of the United States Government. Neither the United States Government nor any agency thereof, nor any of their employees, makes any warranty, express or implied, or assumes any legal liability or responsibility for the accuracy, completeness, or usefulness of any information, apparatus, product, or process disclosed, or represents that its use would not infringe privately owned rights. Reference herein to any specific commercial product, process, or service by trade name, trademark, manufacturer, or otherwise, does not necessarily constitute or imply its endorsement, recommendation, or favoring by the United States Government or any agency thereof. The views and opinions of authors expressed herein do not necessarily state or reflect those of the United States Government or any agency thereof. 
Reactor \& Nuclear Systems Division

\title{
LOCA FRAGMENTATION TEST WITH HIGH BURNUP HBR FUEL ROD
}

\author{
Yong Yan \\ Zach Burns \\ Tyler Smith \\ Kory D. Linton \\ Ken Yeuh (EPRI) \\ Kurt A. Terrani
}

July 2019

Prepared by OAK RIDGE NATIONAL LABORATORY

Oak Ridge, TN 37831-6283

managed by

UT-BATTELLE, LLC

for the

US DEPARTMENT OF ENERGY

under contract DE-AC05-00OR22725 



\section{CONTENTS}

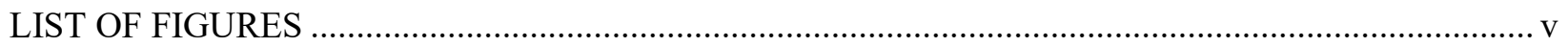

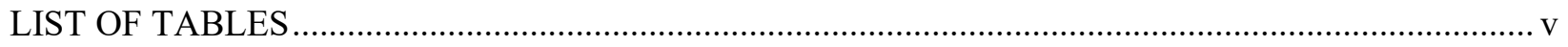

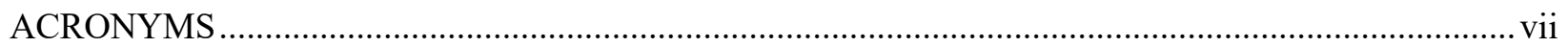

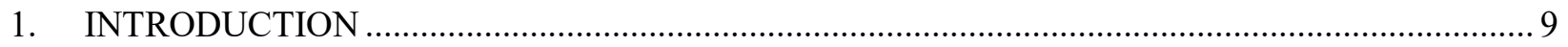

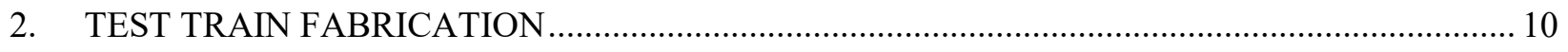

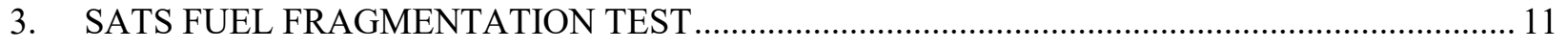

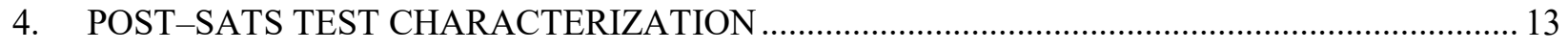

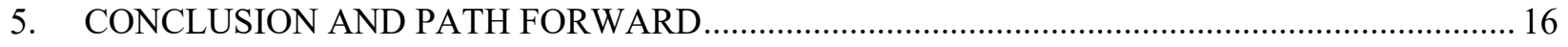

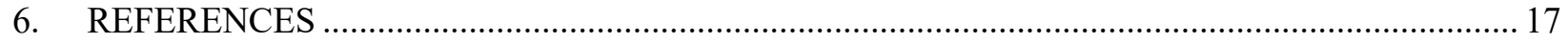





\section{LIST OF FIGURES}

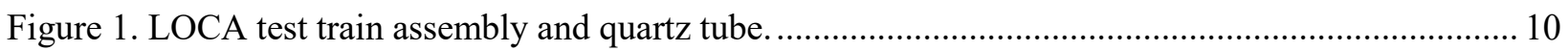

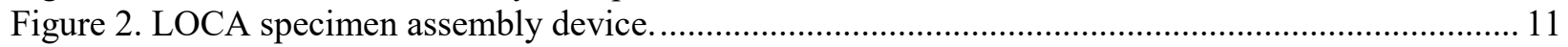

Figure 3. The Severe Accident Test Station pictured after it was placed in-cell at the IFEL................... 12

Figure 4. Temperature and pressure histories for the in-cell LOCA fragmentation test HBR\#1............... 12

Figure 5. Posttest appearance of LOCA fragmentation test sample HBR\#1 in (a) low-

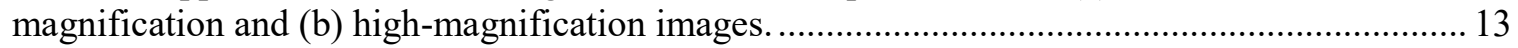

Figure 6. Outer-diameter strain for in-cell LOCA fragmentation test HBR\#1 sample............................. 14

Figure 7. Fragmented fuel particles collected from LOCA fragmentation test HBR\#1 .......................... 15

Figure 8. Images of fragmented fuel particles collected from LOCA fragmentation test HBR\#1:

(a) $<0.125 \mathrm{~mm}$; (b) $0.125-0.250 \mathrm{~mm}$; (c) $0.250-0.500 \mathrm{~mm}$; (d) $0.500-1.00 \mathrm{~mm}$; (e) 1.00 $2.00 \mathrm{~mm}$; and (f) $>2.00 \mathrm{~mm}$.

Figure 9. Size distribution of fuel fragments collected after ORNL LOCA fragmentation and shake testing.

\section{LIST OF TABLES}

Table 1. Summary of international accident testing capabilities

Table 2. Comparison of the ORNL in-cell LOCA fragmentation/integral tests with a previous test performed at ANL on a high burnup specimen. 



\section{ACRONYMS}

$\begin{array}{ll}\text { ANL } & \text { Argonne National Laboratory } \\ \text { BDBA } & \text { beyond design basis accident } \\ \text { HBR } & \text { H. B. Robinson } \\ \text { IFEL } & \text { Irradiated Fuels Examination Facility } \\ \text { INL } & \text { Idaho National Laboratory } \\ \text { LWR } & \text { light water reactor } \\ \text { LOCA } & \text { loss-of-coolant accident } \\ \text { NSUF } & \text { Nuclear Science User Facilities } \\ \text { ORNL } & \text { Oak Ridge National Laboratory } \\ \text { SATS } & \text { Severe Accident Test Station }\end{array}$





\section{INTRODUCTION}

Fuel rod cladding is the first barrier for retention of fission products in light water reactor (LWR) cores, in which the structural integrity of the cladding ensures safe operation of the reactor and coolable core geometry. Zirconium-based alloys have been optimized for use in LWRs over the past five decades, focusing on, among other characteristics, decreasing the waterside corrosion rate and hydrogen pickup under normal operating conditions to increase the operational economy and safety margin. However, nuclear utilities are now confronted with two pressing safety issues: higher-burnup fuel operation and used-fuel dry storage. In relation to the first issue, the damage to the Fukushima Daiichi nuclear facilities in Japan caused by the loss-of-coolant accidents has underscored the importance of factoring severe accidents into nuclear reactor safety research and analyses. In terms of used-fuel dry storage, the United States has focused efforts on disposing of used nuclear fuel in a geologic repository. This project is intended to generate data to inform industry and regulatory agencies to enable them to best address fuel fragmentation in standard LWR fuel designs irradiated to high burnup. ${ }^{1}$ This approach will require reconditioning of irradiated fuel in a reactor at specific power levels and simulated loss-of-coolant accident (LOCA) testing in hot-cell furnaces.

The high-temperature steam oxidation behavior of zirconium alloy cladding under design basis LOCAs and over a broader set of conditions has been studied at several facilities around the world. ${ }^{2-9}$ Table 1 summarizes the available international LOCA testing capabilities. Oak Ridge National Laboratory (ORNL) has developed the Severe Accident Test Station (SATS), located at the Irradiated Fuels Examination Facility (IFEL) at ORNL, that is capable of testing nuclear fuel rods subjected to a range of accident scenarios. The capabilities of SATS include exposing a fuel rod segment to conditions typical of design basis accident and beyond design basis accident (BDBA) scenarios. The specifics of the SATS design have been extensively covered in previous ORNL reports. ${ }^{10,11}$ SATS consists of two modules: one for integral testing of LOCA scenarios and the other with a high-temperature furnace for testing fuel segments.

Table 1. Summary of international accident testing capabilities

\begin{tabular}{|c|c|c|c|c|c|c|c|c|}
\hline Lab & $\begin{array}{l}\text { Heating } \\
\text { Method }\end{array}$ & $\begin{array}{c}\text { Temperature } \\
\text { Control }\end{array}$ & $\begin{array}{l}\text { Temperature } \\
\text { Measurement }\end{array}$ & $\begin{array}{l}\text { Out of } \\
\text { Cell }\end{array}$ & $\begin{array}{l}\text { In } \\
\text { Cell }\end{array}$ & Fuel & $\begin{array}{l}\text { Target Max. } \\
\text { Temperature }\end{array}$ & Ref. \# \\
\hline $\begin{array}{l}\text { ORNL's } \\
\text { SATS }\end{array}$ & $\begin{array}{c}\text { Radiant }+ \\
\text { (Resistance) }\end{array}$ & Computer & TCs & Yes & Yes & Yes & $\begin{array}{c}1,200^{\circ} \mathrm{C} \\
\left(1,600^{\circ} \mathrm{C}\right)\end{array}$ & $\begin{array}{l}\text { This } \\
\text { report }\end{array}$ \\
\hline ANL & Radiant & Computer & TCs & Yes & Yes & No & $1,200^{\circ} \mathrm{C}$ & 4,6 \\
\hline $\begin{array}{l}\text { CEA- } \\
\text { Saclay }\end{array}$ & Resistance & Manual & Preset & Yes & No & No & $1,200^{\circ} \mathrm{C}$ & 7 \\
\hline Halden & $\begin{array}{c}\text { Reactor+ } \\
\text { Heaters }\end{array}$ & Preset & TCs & No & No & Yes & $1,200^{\circ} \mathrm{C}$ & 10 \\
\hline JAEA & Radiant & Computer & TCs & Yes & Yes & No & $1,200^{\circ} \mathrm{C}$ & 5,11 \\
\hline Studsvik & Radiant & Computer & TCs & No & Yes & Yes & $1,200^{\circ} \mathrm{C}$ & 12 \\
\hline $\begin{array}{l}\text { ANL: Arg } \\
\text { CEA: Co } \\
\text { JAEA: Jar } \\
\text { ORNL: O } \\
\text { SATS: Se } \\
\text { TC: therm }\end{array}$ & $\begin{array}{l}\text { Ine National L } \\
\text { missariat à } 1 \\
\text { Atomic Ener } \\
\text { Ridge Nationa } \\
\text { re Accident Te } \\
\text { ouple }\end{array}$ & $\begin{array}{l}\text { boratory } \\
\text { énergie atomi } \\
\text { y Agency } \\
\text { l Laboratory } \\
\text { t Station }\end{array}$ & & & & & & \\
\hline
\end{tabular}


This report documents the test train fabrication, SATS fuel fragmentation test, and post-SATS test characterization under the US Department of Energy Office of Nuclear Energy Nuclear Science User Facilities (NSUF) program.

\section{TEST TRAIN FABRICATION}

SATS was installed in the ORNL 3525 Hot Cell in 2017. ${ }^{11}$ Several LOCA benchmark tests were performed with unindicated Zry-4 cladding specimens before and after the installation. ${ }^{12}$ For irradiated fuels, specimen fabrication for the LOCA fragmentation testing includes fuel rod sectioning, metallographic mounting and polishing, fuel leaching, outer oxide layer removal, inner fuel/cladding bond layer and fuel removal, and end-plug welding. The details of the LOCA sample preparation are provided in previous reports. ${ }^{12,13}$

Figure 1 shows the LOCA test train with as-fabricated cladding. The test train is supported at the top to minimize specimen bowing. The quartz tube encasing the test train provides an enclosed volume for steam flow and water quench, both of which are introduced through the bottom of the unit. The test train is centered within the quartz tube by means of two perforated spacer disks. Swagelok fittings are used above the specimen to connect to the high-pressure gas line and top pressure gauge and below the specimen to connect to the bottom pressure-gauge line. For out-of-cell benchmark tests, Type $S$ thermocouples are spot-welded directly to the specimen surface. The signal from one thermocouple is used to control the furnace power to achieve the desired temperature ramp, hold temperature, and cooling rate prior to quench.

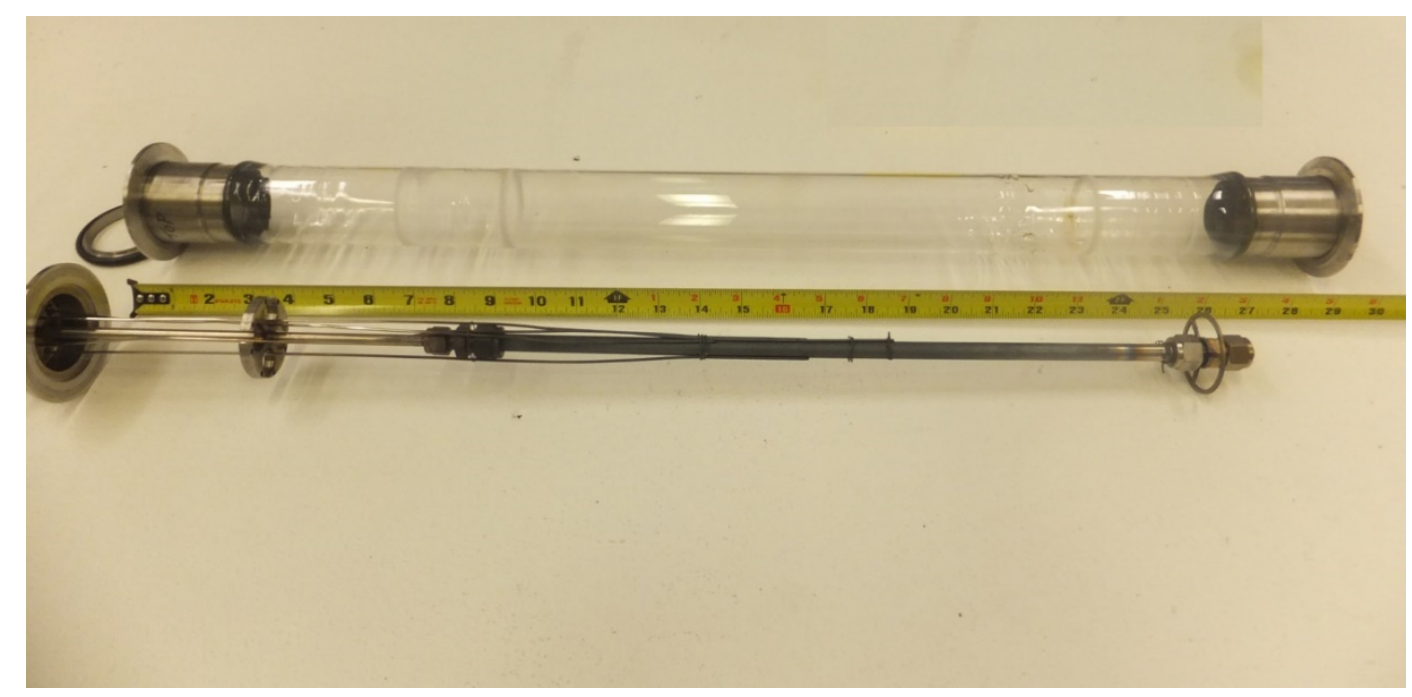

Figure 1. LOCA test train assembly and quartz tube. The 300-mm-long specimen is centered with two centering disks.

For in-cell LOCA tests, Type $\mathrm{S}$ thermocouples are strapped to the irradiated fuel specimen with platinum wire at $50 \mathrm{~mm}$ above the midplane of a 12 -in.-long specimen. A LOCA specimen assembly device was fabricated to assemble the fuel segment, as shown in Figure. 2. 


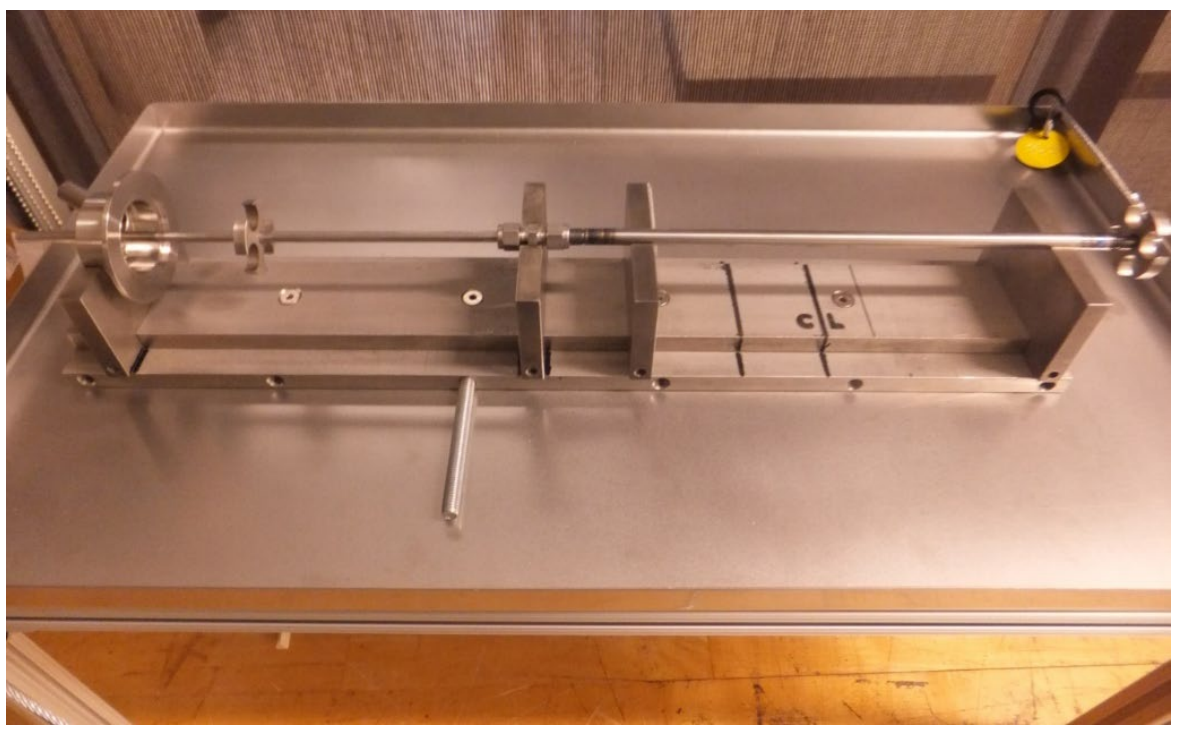

Figure 2. LOCA specimen assembly device.

\section{SATS FUEL FRAGMENTATION TEST}

The SATS LOCA test apparatus for this experiment is shown in Figure 3. Figure 4 shows the temperature and pressure histories for the in-cell LOCA fragmentation test HBR\#1. A high burnup pressurized water reactor H. B. Robinson (HBR) segment was used for the fuel fragmentation test. After the fuel specimen was assembled to the test train, two Type-S thermocouples were strapped to the outer surface of the cladding approximately $2 \mathrm{in}$. above the sample centerline. One of these was used to control the furnace power to give a hold temperature of $1,000^{\circ} \mathrm{C}$ at that location. The other thermocouple, adjacent to the control thermocouple, was used as a backup thermocouple to record temperature in the event that the control thermocouple failed. Based on out-of-cell benchmark testing of unirradiated $17 \times 17$ Zry- 4 , the difference in output between a strapped and a welded thermocouple at the same location is $<10^{\circ} \mathrm{C}$. The fragmentation test was conducted in steam at $1,000^{\circ} \mathrm{C}$, but without water quench. The full LOCA fragmentation test sequence included

- heating in flowing steam to $300^{\circ} \mathrm{C}$ and pressurizing fuel segment to $1,200 \mathrm{psi}$,

- heating in flowing steam at $5^{\circ} \mathrm{C} / \mathrm{s}$ from $300^{\circ} \mathrm{C}$ to $1,000^{\circ} \mathrm{C}$,

- $\quad$ holding in steam for $120 \mathrm{~s}$ at $1,000^{\circ} \mathrm{C}$,

- cooling at $3^{\circ} \mathrm{C} / \mathrm{s}$ to $800^{\circ} \mathrm{C}$, and

- furnace cooling from $800^{\circ} \mathrm{C}$ to room temperature. 


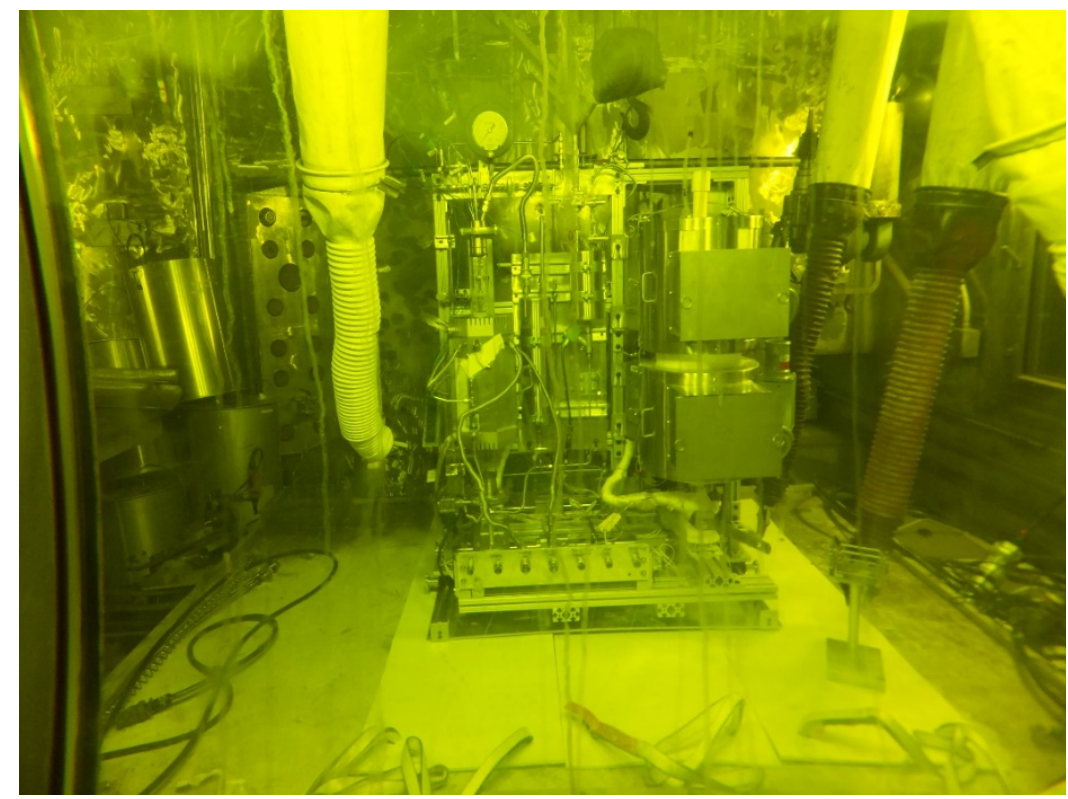

Figure 3. The Severe Accident Test Station pictured after it was placed in-cell at the IFEL. The test station includes the integral LOCA testing module (left) and the BDBA high-temperature furnace test apparatus (right).

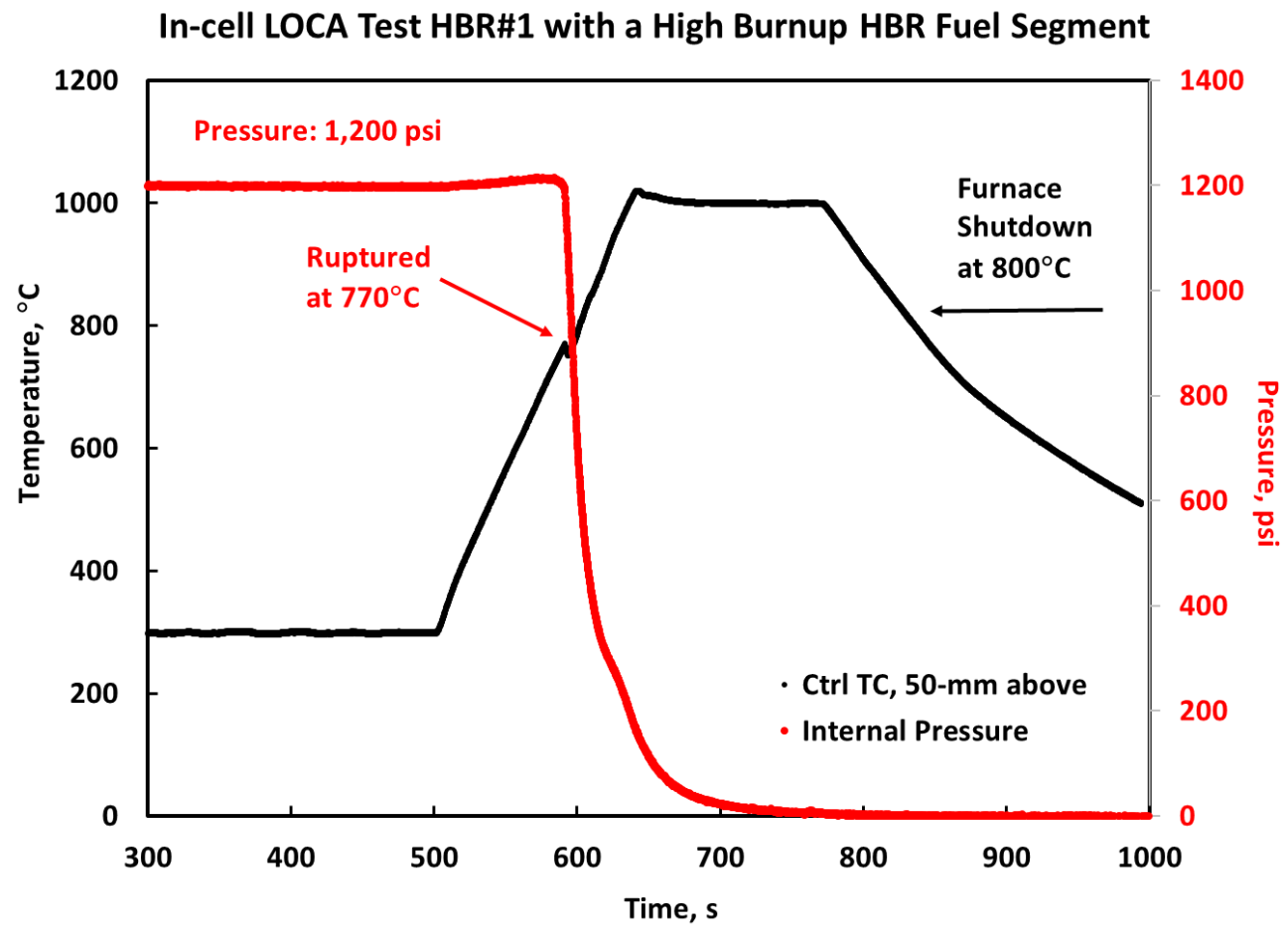

Figure 4. Temperature and pressure histories for the in-cell LOCA fragmentation test HBR\#1. 


\section{POST-SATS TEST CHARACTERIZATION}

Figure 5 shows the post-test LOCA fragmentation test HBR\#1 sample. Sieve analysis and strain measurement were performed. Table 2 summarizes the result of the two ORNL in-cell tests with high burnup North Anna and HBR cladding specimens and the result of a LOCA test that was conducted with high burnup Limerick Zry-2 at Argonne National Laboratory (ANL). The ORNL North Anna specimen ${ }^{13}$ was tested in a full LOCA sequence similar to the test conditions of ANL ICL\#4, and the ORNL HBR specimen was tested up to $1,000^{\circ} \mathrm{C}$ without water quench. Although the cladding geometry and cladding material were different between these tests, their burst temperatures were remarkably close. However, the HBR sample had a relatively small balloon and burst opening, as shown in Table 2. The profile of diametral strain for HBR\#1 is shown in Figure 6.

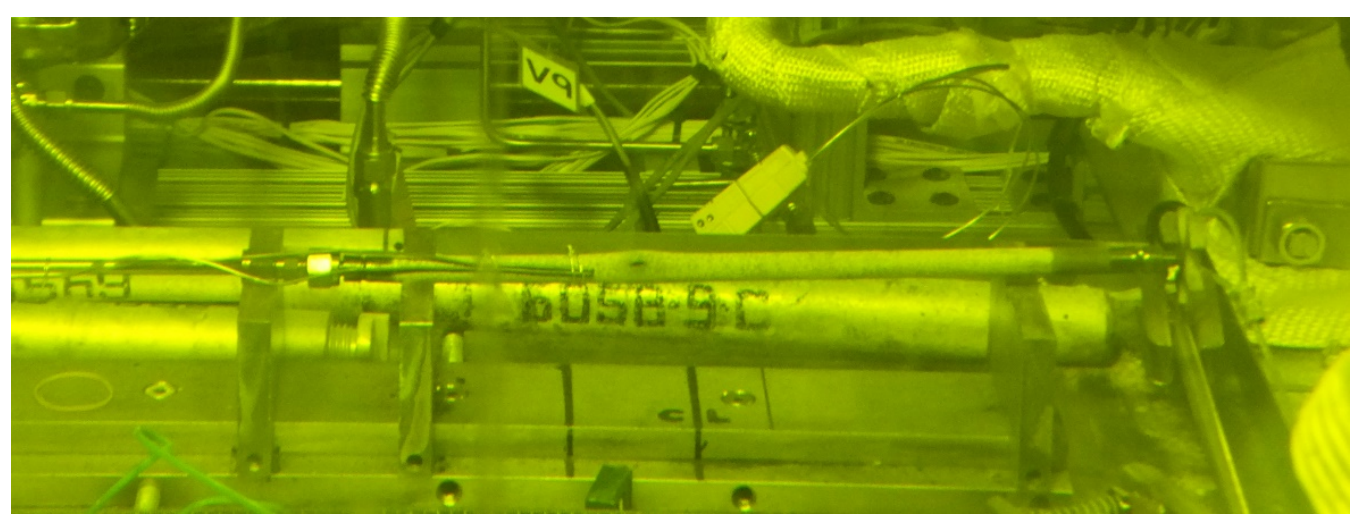

(a)

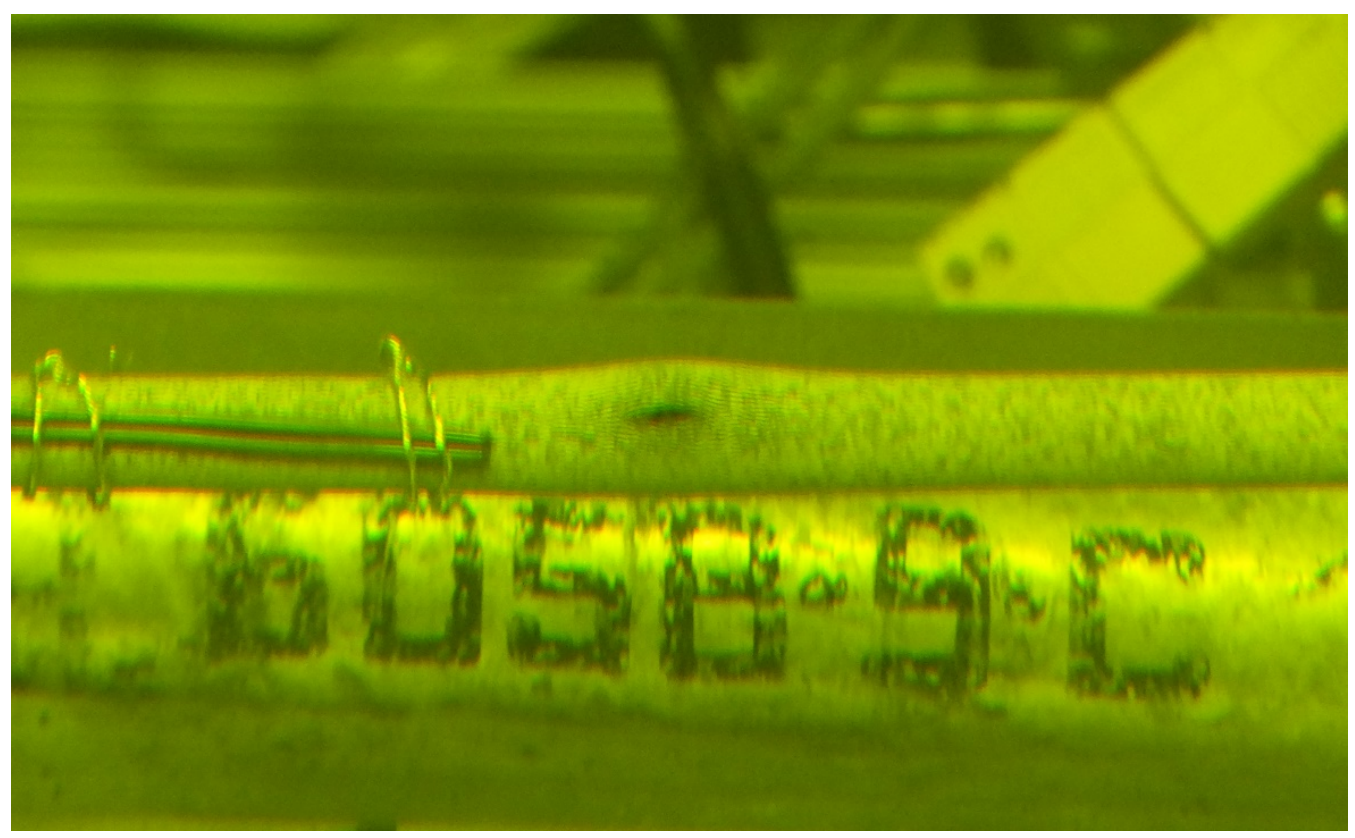

(b)

Figure 5. Posttest appearance of LOCA fragmentation test sample HBR\#1 in (a) low-magnification and (b) high-magnification images. 
Table 2. Comparison of the ORNL in-cell LOCA fragmentation/integral tests with a previous test performed at ANL on a high burnup specimen

\begin{tabular}{cccc}
\hline Parameter & ORNL HBR\#1 & ORNL NA\#1 & ANL ICL\#4 \\
\hline Fuel & H.B. Robinson & North Anna & Limerick \\
Materials & Zircaloy-4 & M5 & Zircaloy-2 \\
Burnup, GWd/MT & $63-67$ & 67 & $54-57$ \\
Outside diameter, $\mathrm{mm}$ & 10.76 & 11.18 & 9.5 \\
Wall thickness, $\mathrm{mm}$ & 0.76 & 0.71 & 0.57 \\
Internal pressure at $300^{\circ} \mathrm{C}, \mathrm{psi}$ & 1,200 & 1,200 & 1,200 \\
Temperature ramp from $300^{\circ} \mathrm{C},{ }^{\circ} \mathrm{C} / \mathrm{s}$ & 5 & 5 & 5 \\
Peak internal $\mathrm{P}_{\mathrm{g}}, \mathrm{psi}$ & 1,213 & 1,214 & 1,285 \\
Temperature at burst, ${ }^{\circ} \mathrm{C}$ & 770 & 791 & 790 \\
Hold temperature, ${ }^{\circ} \mathrm{C}$ & 1,000 & 1,200 & 1,200 \\
Hold time, $\mathrm{s}$ & 120 & 90 & 300 \\
Cool-down rate to $800^{\circ} \mathrm{C},{ }^{\circ} \mathrm{C} / \mathrm{s}$ & 3 & 3 & 3 \\
Quench initiation temperature, ${ }^{\circ} \mathrm{C}$ & - & 800 & 800 \\
Burst shape & Oval & Oval & Oval \\
Burst length, $\mathrm{mm}$ & 7 & 16 & 15 \\
Max. burst width, $\mathrm{mm}$ & $\sim 2$ & $\sim 3$ & 5.1 \\
Max. strain $\left(\Delta \mathrm{C} / \mathrm{C}_{\mathrm{m}}\right)_{\max },{ }^{\circ} \%$ & 25 & 41 & 36 \\
\hline
\end{tabular}

LOCA Fragmentation Test HBR\#1 with High Burnup HBR Zircaloy-4 at $1000^{\circ} \mathrm{C}$

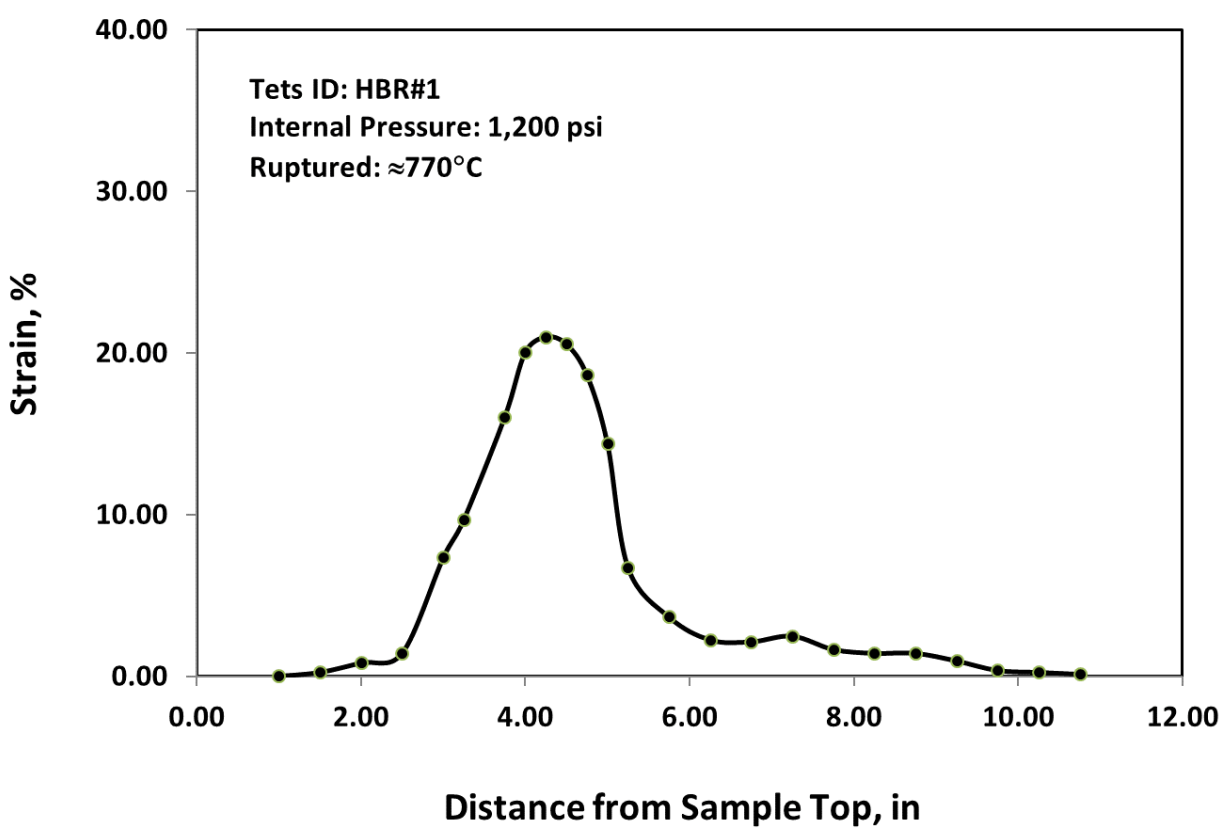

Figure 6. Outer-diameter strain for in-cell LOCA fragmentation test HBR\#1 sample. The sample was ramped to $1,000^{\circ} \mathrm{C}$, held at $1,000^{\circ} \mathrm{C}$ for $120 \mathrm{~s}$, cooled to $800^{\circ} \mathrm{C}$ at $3^{\circ} \mathrm{C} / \mathrm{s}$, and then furnace-cooled to room temperature. 
Images of the fuel rod and fuel fragments from HBR\#1 are shown in Figure 7. The total fuel collected from HBR\#1 was $59.8 \mathrm{~g}$. A few fine particles can be seen in Figure 7. The fragment size distribution of the fuel collected after LOCA fragmentation and shake testing of the HBR\#1 sample was quantified, and the result is shown in Figures 8 and 9.

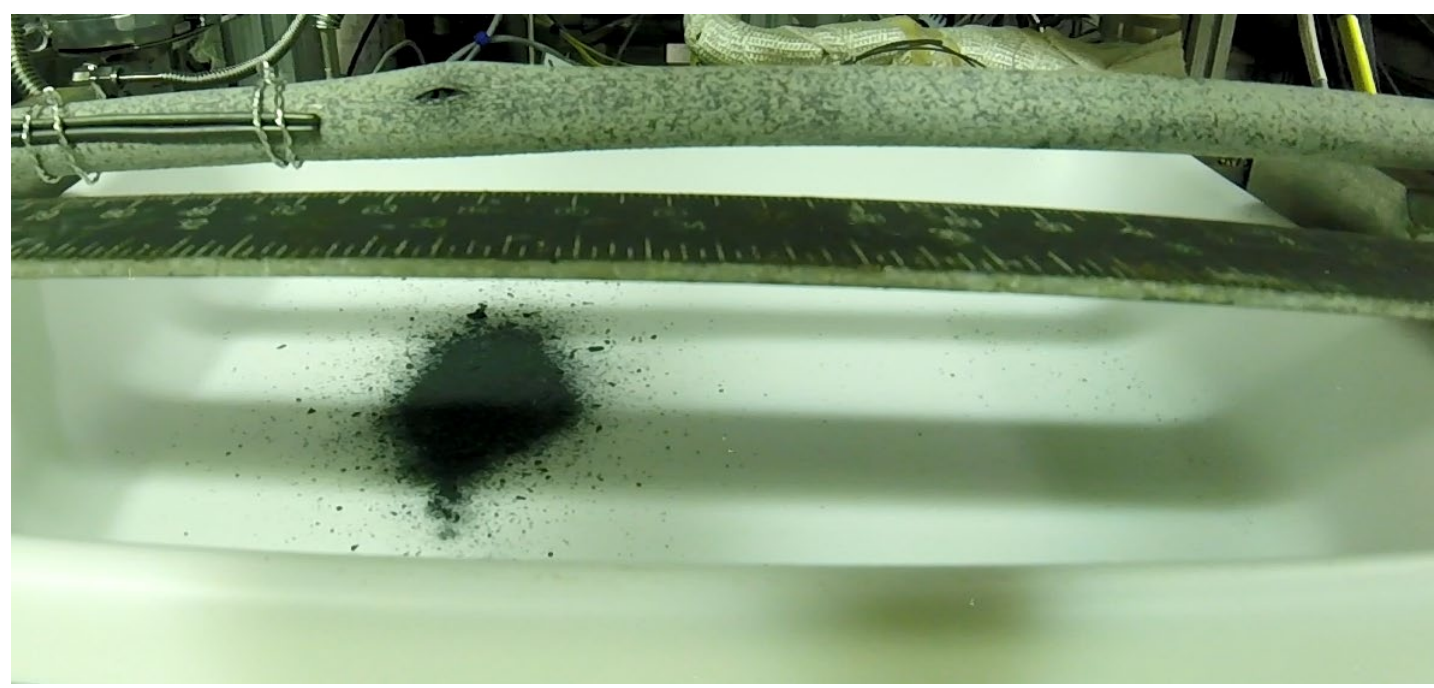

Figure 7. Fragmented fuel particles collected from LOCA fragmentation test HBR\#1.

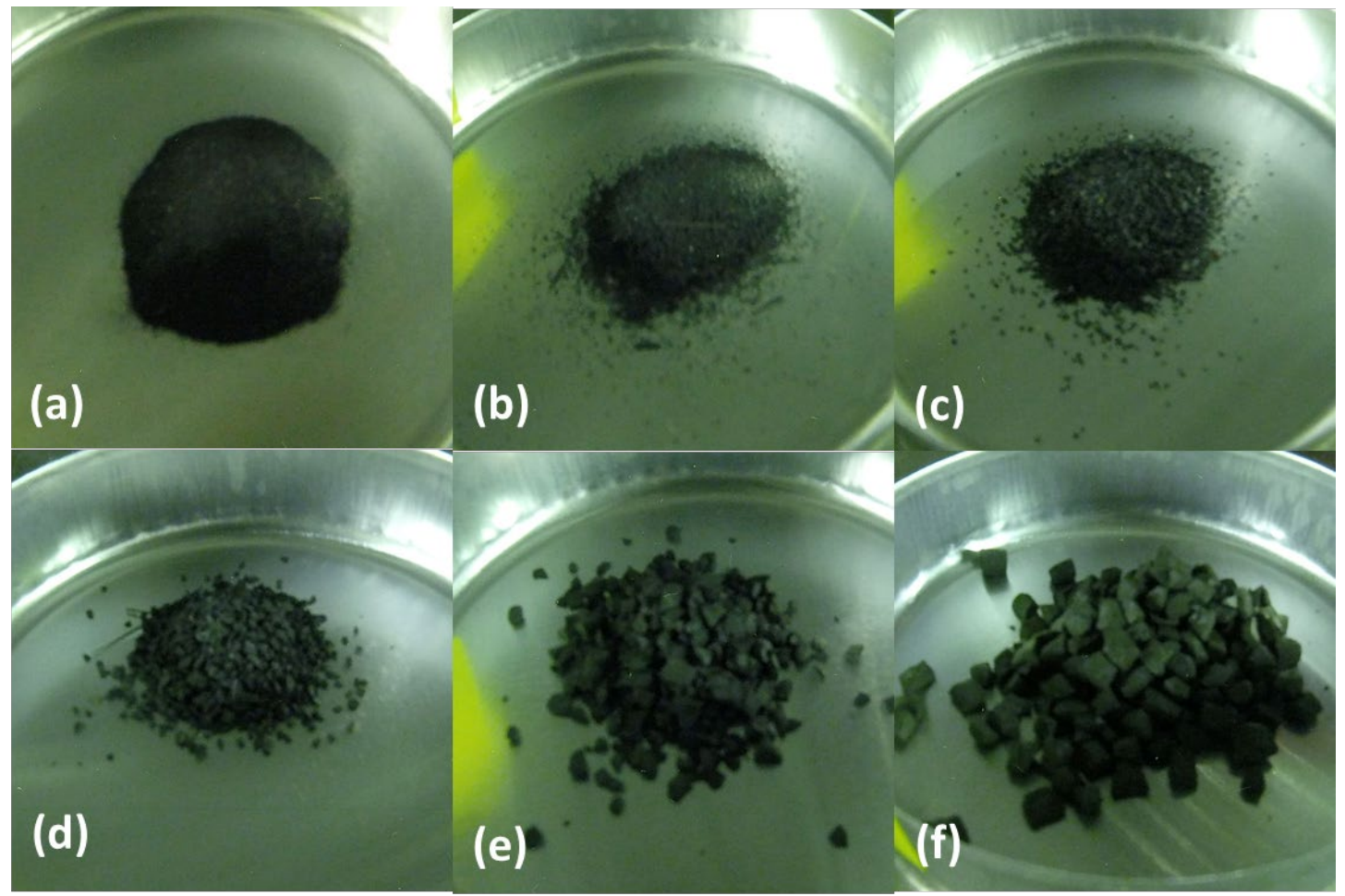

Figure 8. Images of fragmented fuel particles collected from LOCA fragmentation test HBR\#1: (a) <0.125 $\mathrm{mm}$; (b) 0.125-0.250 mm; (c) 0.250-0.500 mm; (d) 0.500-1.00 mm; (e) 1.00-2.00 mm; and (f) $>2.00 \mathrm{~mm}$. 


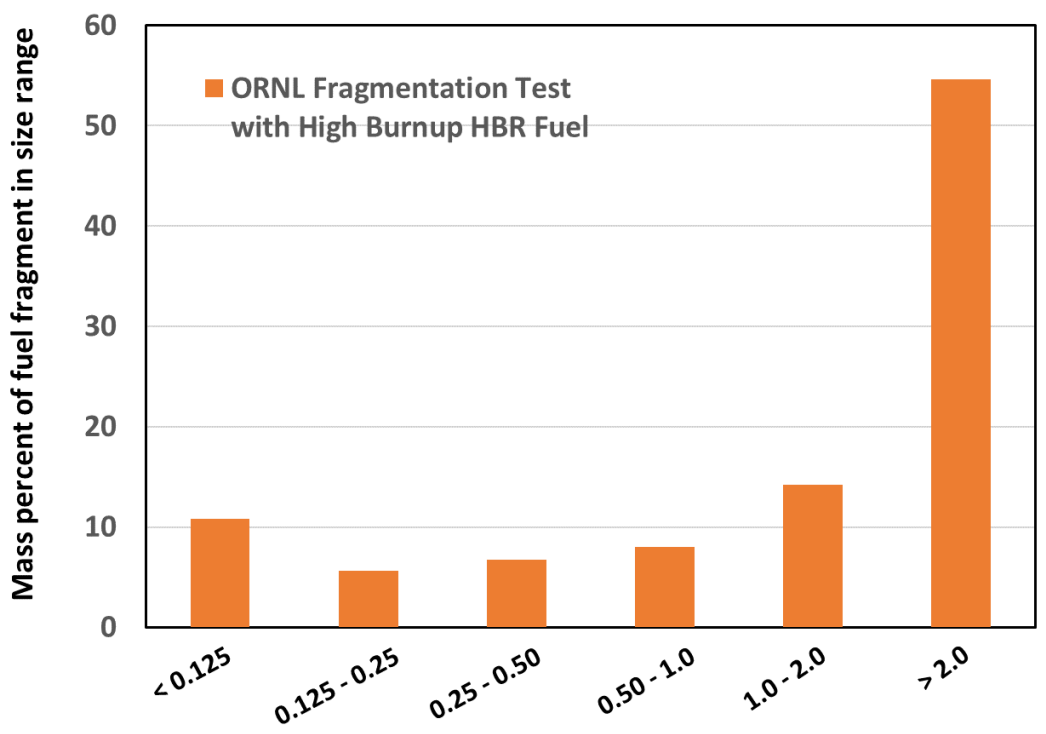

Size distribution of the fuel fragments, $\mathrm{mm}$

Figure 9. Size distribution of fuel fragments collected after ORNL LOCA fragmentation and shake testing.

\section{CONCLUSION AND PATH FORWARD}

SATS was successfully used to perform a LOCA fragmentation test with a high burnup HBR fuel segment. Experimental data is necessary to inform industry and regulatory agencies on the fuel fragmentation behavior of standard LWR fuel designs irradiated to high burnup.

In addition, the results from integral LOCA tests, including those that will be performed in SATS, provide valuable data for code and modeling validation, which enhances the ability to predict the behavior of fuel systems during accident scenarios. Validation of nuclear fuel performance codes, such as BISON, will provide results that can either act as a screening tool for future experiments or be coupled with experimental data to validate the behavior of a fuel system during safety testing. ${ }^{14,15}$

The NSUF award supporting this work will continue with ORNL refabrication of commercial fuel into rodlets for irradiation to higher burnup at the Idaho National Laboratory (INL) Advanced Test Reactor. Fuel fragmentation of these higher burnup rodlets during transients can then be tested at the INL Transient Reactor Test Facility, known as "TREAT." 


\section{REFERENCES}

1. D. Jadernas, K. Yueh, M. Bales, D. Wachs, K. Terrani, K. Linton, N. Meacham, Sample Selection Report for the Irradiation and Post Irradiation Examination of Ultra High Burnup Fuel, INL/EXT-1744054, January 2018.

2. L. Baker and L. C. Just, Studies of Metal-Water Reactions at High Temperatures: III. Experimental and Theoretical Studies of the Zirconium-Water Reaction, ANL-6548, May 1962.

3. J. V. Cathcart, R. E. Pawel, R. A. McKee, R. E. Druschel, G. J. Yurek, J. J. Cambell, and S. H. Jury, Zirconium Metal-Water Oxidation Kinetics: IV. Reaction Rate Studies, ORNL/NUREG-17, August 1977.

4. Y. Yan, R. V. Strain, T. S. Bray, and M. C. Billone, "High Temperature Oxidation of Irradiated Limerick BWR Cladding,” NUREG/CP-0176 (May 2002), 353-372.

5. F. Nagase, T. Otomo, and H. Uetsuka, "Oxidation Kinetics of Low-Sn Zircaloy at the Temperature Range from 773 to 1571K," Journal of Nuclear Science and Technology 40 (2003), 213-219.

6. M. Billone, Y. Yan, T. Burtseva, and R. Daum, Cladding Embrittlement During Postulated Loss-ofCoolant Accidents, NUREG/CR-6967, ANL-07/04, July 2008.

7. J.-P. Mardon, D. Charquet, and J. Senevat, "Influence of Composition and Fabrication Process on Outof-Pile and In-Pile Properties of M5 Alloy," Zirconium in the Nuclear Industry: 12th International Symposium, ASTM STP 1354, G. P. Sabol and G. D. Moan, eds., American Society for Testing and Materials, West Conshohocken, PA, (2000), 505-524.

8. R. J. Comstock, G. Schoenberger, and G. P. Sabol, "Influence of Processing Variables and Alloy Chemistry on the Corrosion Behavior of ZIRLO Nuclear Fuel Cladding," Zirconium in the Nuclear Industry: 11th International Symposium, ASTM STP 1295, E. R. Bradley and G. P. Sabol, eds., American Society for Testing and Materials (1996), 710-725.

9. Y. Yan, T. Burtseva, and M. Billone, "High-Temperature Steam-Oxidation Behavior of Zr-1 $\mathrm{Nb}$ Cladding Alloy E1 10.” Journal of Nuclear Materials, 393 (2009), 433-448.

10. M. Snead, Y. Yan, M. Howell, J. Keiser, and K. Terrani, Severe Accident Test Station Design Document, ORNL/TM-2015/556, Oak Ridge National Laboratory, September 2015.

11. K. Linton, Y. Yan, Z. Burns, and K. Terrani, Hot Cell Installation and Demonstration of the Severe Accident Test Station, ORNL/SPR-2017/434, Oak Ridge National Laboratory, August 2017.

12. Y. Yan, Z. Burns, K. Linton, and K. A. Terrani, "Results from In-cell Integral LOCA Testing at ORNL," 2017 WRFPM, Jeju Island, Korea, September 10-14, 2017.

13. A. Raftery, Y. Yan, T. Smith, Z. Burns, K. Terrani, and K. Linton, Severe Accident Test Station HotCell Installation and Demonstration Test, ORNL/TM-2018/89, June 2018.

14. B. Hanson, S. Marschman, M. Billone, J. Scaglione, K. Sorenson, and S. Saltzstein, High Burnup Spent Fuel Data Project Sister Rod Test Plan Overview, PNNL-25374, Pacific Northwest National Laboratory, April 2016.

15. D. Perez, R. Williamson, S. Novascone, G. Pastore, J. Hales, and B. Spencer, Assessment of BISON: A Nuclear Fuel Performance Analysis Code, NEUP.INL.GOV, Idaho National Laboratory, November 2013. 